\title{
Emotional branding analysis for the Korean Drama-based tourism locations
}

\section{Analisis branding emosional untuk lokasi pariwisata berbasis Drama Korea}

\author{
$\underline{\text { Amida Yusriana }}^{1}$, Devi Purnamasari ${ }^{1}, \&$ Nalal Muna ${ }^{2}$ \\ ${ }^{1}$ Department of Communication Studies, Faculty of Computer Science, Universitas Dian Nuswantoro \\ ${ }^{2}$ Department of Management, Politeknik Negeri Akademi Pimpinan Perusahaan Jakarta \\ Address: ' Jalan Imam Bonjol No.207, Semarang, Central Java 50131 \\ ${ }^{2}$ Jalan Timbul No.34, Jagakarsa, Jakarta 12630 \\ E-mail: amida.yusriana@dsn.dinus.ac.id
}

\begin{abstract}
City branding is an effort to build a particular image of a city. Semarang is one of Indonesia's big cities that has not yet succeeded in finding the right brand to represent it. The researcher has conducted a pilot research study that aims to build Semarang's city branding as The Cinematic City. It is due to Semarang's background of often becoming a shoot location for famous movies. South Korea is well known because of its pop cultures, such as drama. Drama is one of the main factors that contribute to the increasing number of foreign visitors. They mostly visit popular drama shooting locations as their destinations. These kinds of tourism site are successful at developing emotional branding in the visitor's minds. Looking at the similarity of South Korea and Semarang will help Semarang to learn a lot from what South Korea has done. This research aims to analyse how emotional branding represented through the Korean drama-based tourism site gimmicks. This research used the Emotional Branding theory by Marc Gobe. It assumed that emotional bonding is an essential thing in terms of engaging the customer and product in a particular phase. The main subjects of this research are the gimmicks in Nami Island. The result shows that the Relationship Aspect fulfilled by changing the theme and properties according to the season. For the Five Senses Experience, it only employs the sense of sight and touch by creating many gimmicks that can be a photo-taking hot spot. The Imagination aspect fulfilled by the unique design of the Emotional Identity put forward, such as the snowman.
\end{abstract}

Keywords: city branding; tourism; emotional branding; South Korea; Semarang

\begin{abstract}
Abstrak
City Branding adalah upaya membangun citra tertentu pada sebuah kota. Semarang adalah salah satu kota besar di Indonesia yang belum berhasil dalam menemukan citra yang dapat merepresentasikan karakteristiknya. Peneliti telah melakukan penelitian sebelumnya yang bertujuan untuk membangun City Branding Semarang sebagai Kota Film. Hal ini didasarkan pada latar belakang Semarang yang sering menjadi lokasi syuting film terkenal. Korea Selatan terkenal karena budaya populernya, yaitu drama. Drama adalah salah satu faktor utama yang berkontribusi dalam meningkatkan jumlah wisatawan mancanegara. Banyak dari wisatawan mengunjungi lokasi syuting drama terkenal. Wisata semacam ini berhasil dalam mengembangkan emotional branding pada pikiran pengunjung. Menilik kesamaan antara Korea Selatan dan Semarang akan membantu dalam mempelajari strategi Korea Selatan. Tujuan dari penelitian ini adalah untuk menganalisa bagaimana Emotional Branding dipresentasikan melalui gimmick drama yang ada di tempat wisata.Penelitian ini menggunakan teori Emotional Branding oleh Marc Gobe yang berasumsi bahwa ikatan emosional adalah penting dalam mengikat konsumen dan produk dalam tahap tertentu. Subyek utama dari penelitian ini adalah Nami-Island. Hasil menunjukkan bahwa aspek hubungan dipenuhi dengan perubahan tema dan properti mengikuti musim. Sedangkan pengalaman lima panca indera hanya menggunakan indera penglihatan dan peraba dengan memberikan banyak gimmicks. Aspek imajinasi dipenuhi degan desain unik pada identitas emosional film seperti adanya patung-patung manusia salju.
\end{abstract}

Kata kunci: city branding; wisata; emotional branding; Korea Selatan; Semarang

\section{Introduction}

Simon Anholt in Moilanen and Rainisto (2009: 7) defined city branding as the image management of certain destination using strategic innovation and economy coordination, in addition to involving commercial, social, culture and public policy. According to Kavaratzis (2008: 8), city branding mostly 
focuses on the management of image, in particular how the image is built and the communication aspect. City branding is an important and interesting topic for both academics and policy makers. There is a rivalry between cities to attract tourists. investment and talent, and to achieve more objectives. The concept of this form of brand strategy has been adopted from the commercial world and it is practical in terms of catching up with urban scale development, regeneration and quality of life (Dinnie 2011: 30).bBranding can be varied. There are three indicators: the place may mean much the same thing to most people who are aware of it. This means that it has a strong reputation. If the place means very little to most people who are aware of it, or they believe widely different things depending on who you ask, then it has a weak reputation. If it is known by a lot of people, then it is a famous place (Kazima et al. 2016: 167).

Five critical antecedents of successful destination branding have been identified: stakeholder partnerships, brand leadership, departmental coordination, brand communications and brand culture. Two key mediating factors were also identified: brand reality and brand architecture (Hankinson 2009: 97). Semarang is the capital city of Central Java Province. It is the biggest city in Central Java province and it is populated by 1.8 million people. Semarang has been actively developing its tourism aspect. It brands itself as 'Variety of Culture' because of the various cultural backgrounds that distinguish Semarang from other cities. These various cultures have become a major asset of Semarang that should be promoted as the main interest of tourism. The effect of various cultures is shown in the richness of the art, architecture, religion, culinary and other events. The culinary and places of worship are diverse, such as the Great Mosque of Central Java, Sam Poo Kong Temple, Tay Kak Sie Temple, Buddhagaya Watugong Monastery, Blendhuk Church, Giri Natha Temple and Avalokitesvara Pagoda. For the culinary facet, there is a mixture between Javanese, Chinese and Arab food. For the cultural side, Semarang consists of the Javanese culture, coastal culture, Arab culture and Chinese culture.

However, this city branding has not yet been successful at achieving the target amount of tourists in Semarang. In fact, this city branding is not yet strong enough to be compared to Yogyakarta and Bali (other big cities in Indonesia). It is also less promoted. In May 2015, the statistical data showed that the domestic tourists that came to Central Java totaled 30 million people. Even so, this number is not only from Semarang but also from international tourism spots such as Borobudur Temple. This temple is in Central Java but not in Semarang. Thus, Semarang does not have a potential tourism spot yet to attract tourists.

There are two other research studies about Semarang's city branding topic. The first one is titled 'The Market Maker's Perception Towards The Image Building's Factors (Semarang's City Branding)' by Asmarani Februandari. This research souht the societal perception of the sample in order to get the needed factors involved in building a city brand. The research was conducted by transmitting a questionnaire to 100 respondents and 6 travel agent representatives using mixed methods. The results show that the factors are uniqueness, cuisine, heritage, a low price, friendliness, youngsters and various cultures (Februandari 2012: 1).

The second research is 'The Effect of City Branding Towards the Decision to Visit Semarang' by Soliha and their colleagues. This research aims to find out the relations between city branding and the city image of Semarang, and how these two factors interplay in the decision to visit Semarang. This research was conducted by using 104 people as the sample. The results depict that City Branding has a positive and significant influence on brand image. This means that better city branding implementation will improve the city image. It also shows that the city image becomes a mediation for the visitor to decide to visit Semarang or not (Soliha et al. 2014: 1). Hence, the researcher conducted a previous study about Semarang's city branding as the Cinematic City. The results show that there are three potential locations for becoming brand attributes for Semarang as The Cinematic City (Yusriana 2018). This previous research is based on the success of several cities such as Oxford in the United Kingdom, Seoul in South Korea and New Zealand due to Lord of The Rings. These places are famous for their shooting locations. It attracts tourists to visit and to feel the film's atmosphere. 
This is a continuation research from those mentioned above. This research is going to seek out the strategy used by the tourist sites in South Korea. The location for this study was Nami Island. Nami Island was chosen because it is the shoot location of a famous drama: Winter Sonata. It has becme a tourist destination because of the drama.

Nami Island has a similar situation to Kota Lama, as one of the previous research results. Nami Island, in Korean language Nami-seom, was formed as a result of the construction of Cheongpyeong Dam. The name is taken from a general named Nami that was buried in the area of Nami Island. He led a great victory against the rebels in the 13th year of the 7th king of the Joseon Dynasty. Nami Island is famous for its beautiful tree-lined road. In the middle of the island, there is a grass field of about 316. 320 square yards. It features education and training facilities and camping sites. The island also has a swimming pool and water sports facilities for motorboats and water skiing, as well as a theme park with a merry-go-round, shooting range, and roller skating rink.

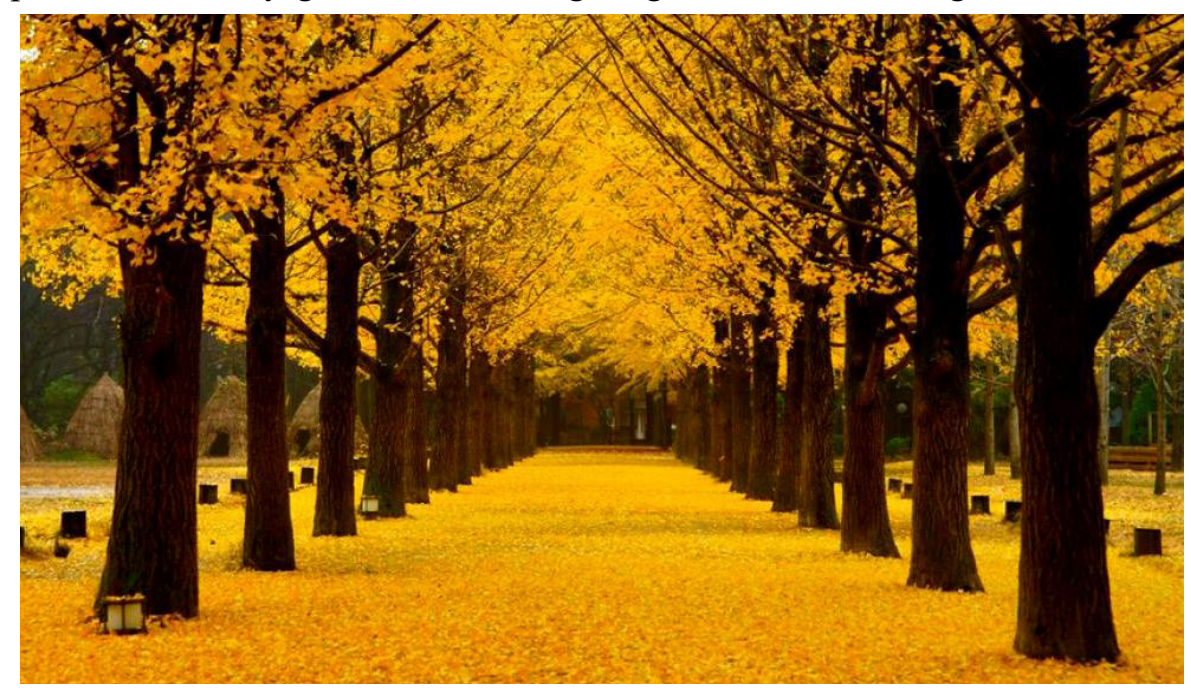

Figure 1.

Nami Island's popular spot

The research question of this study is to understand how emotional branding is represented through the Korean drama-based tourism sites gimmicks.The objective of this research is to analyse how emotional branding is represented through the Korean drama-based tourism sites gimmicks. The objects are limited to Nami Island's gimmicks. The reason for choosing Nami Island is because it has a similar situation to one of Semarang city's objects. The similarity is found in the width of the area and it is used for more than one popular drama/movie.

Winter Sonata is a famous 2002 drama. It was one of the projects of the well-known director, Yoon Seok-Ho. Yoon Seok-Ho has created The Endless Love Series drama that based its story on the seasons of the year. This series consists of four dramas with a tragedy ending as the main characteristic. Autumn in My Heart wass the first one to air in 2000. The story evolved during the autumn season. The second one is Winter Sonata in 2002, using the winter season as the drama's background. The third one is Summer Scent in 2003, in which the summer situation was the main story, while the last one is Spring Waltz in 2006. It uses the beauty of spring days as the background. Winter Sonata is the first drama that has united South Korea and Japan. Since it was broadcast on Japan's television station, it became a national hit. Many Japanese tourists visit South Korea because of this drama and due to their love for the main actor, Bae Yong Joon. South Korea and Japan have had a complicated situation up until now due to their history.

Winter Sonata was broadcast in Japan, America and half of the Asian continent. The story begins when Joon-sang, the son of an eminent musician, moves to Chuncheon, a rural city in South Korea. As an extraordinarily talented student, Joon-sang is welcomed by his fellow students as well as his teachers, but he remains a quiet, introverted teenager. As a result of the belief that his biological father is dead and due to serious disagreements with his mother, Joon-sang believes that no one truly loves him. 
On his way to school one day, Joon-sang's classmate, Yoo-jin, while sitting next to him on the bus, falls asleep on his shoulder. Joon-sang soon falls in love with Yoo-jin, who opens up her innocent heart to him. Their love, however, is cut short after Joon-sang is badly injured in a car accident and, due to brain damage, he suffers from amnesia, unable to remember anything prior to his accident. Joon-sang's mother, yearning for Joon-sang's love and respect, has Joon-sang brainwashed by a psychologist so then Joon-sang will not remember his painful childhood as an illegitimate child. As a result, Joon-sang's memories prior to the accident are erased. Joon-sang's mother decides to move to the United States with Joon-sang, where he can start a new life under the identity of Lee Min-hyeong. His friends and teachers are told that Joon-sang is dead.

Ten years later, Min-hyeong is an award-winning architect in the United States. He does not remember anything about his life in Korea. He is completely different; now he is an open-minded person who cares about other people. He returns to Korea and Yoo-jin sees him on the street, prompting her to put off her engagement to her childhood friend, Sang-hyeok. Little does she know that Min-hyeong is dating her friend and past rival, Chae-rin. The plot thickens when Yoo-jin's interior design firm is awarded a project by Min-hyeong's architectural firm, and so has to work with Min-hyeong. Yoo-jin sometimes wonders if he is her supposedly dead first love, Joon-sang (en.wikipedia.org).

Many of the scenes in this drama were filmed in Nami Island. These include some of the iconic scenes that became popular. For example, "The First Kiss" scene, in which both of the main characters share a bench near the lake of Nami Island. They initially made little snowmen and then the actor lets the snowmen reenact a kissing situation, then followed by the pair of them doing so. This drama created one of the icons of Nami Island during the winter season: the snowman. The other popular scene is bicycle riding. Both of the characters rode a bicycle through the line of gingko trees on Nami Island. Since then, the Gingko treeline become a hot spot for tourists to take pictures.

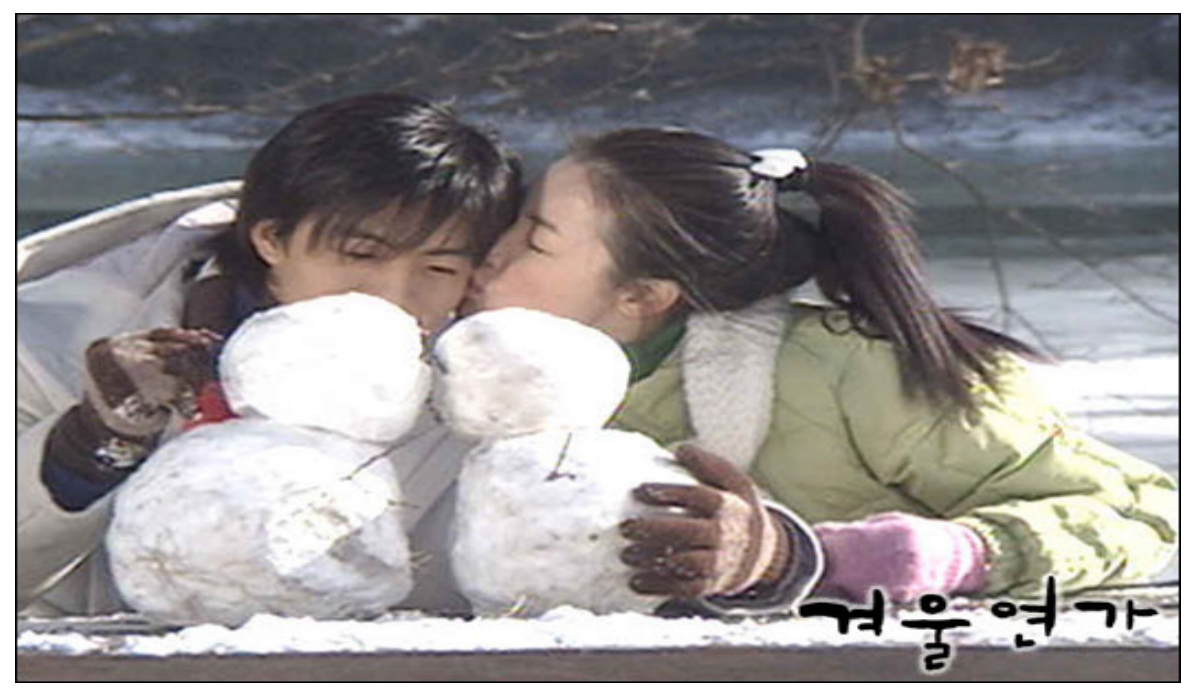

Figure 2.

Kissing scene and the iconic snowman

Winter Sonata is not the only drama taken in Nami Island; there are more. But it is the only one that has become famous beyond the nation. Thus, most of the drama's gimmicks have become icons on Nami Island. The theory used for this study was emotional branding by Marc Gobe. Emotional branding is a medium where people unconsciously connect to the company and product from the company through an emotional method. Emotional branding is a dynamic mixture of anthropology, imagination, sense experience, and visionary approach towards the alteration. Emotional branding focuses on human urgent aspects; the desire for material satisfaction and emotional satisfaction. The basic concepts of the emotional branding process are a relationship, sense experience, imagination and vision (Gobe 2003: 12-28).

Although the words 'brand', 'branding' and 'destination image' has already appeared in many academic studies and industry conferences, no apparent effort has been made to distinguish between 
destination image and destination branding. The purpose of this short commentary is to stimulate thinking on destination branding and to outline its relationship with destination image (Ekinci 2003: 21). Emotional branding is defined as the engagement of consumers in a deep, long-term, intimate emotional connection with a brand, which is beyond benefit-based satisfaction. It creates a special trust-based relationship for the development of a holistic emotional experience (Morrison \& Crane 2007). Customer emotional attachment has been a crucial construct which describes the power and vigor which bonds customers with the brand. Consequently, this bond influences the behavior of the customers, thus increasing the firm's profitability and productivity (Khan 2016: 153). The branding literature has recently focused on the role of emotions as a leveraging force in the attachment of consumers to brands (Yoo \& MacInnis 2005) as suggested through the development of strong brand relationships. Hence, firms ought to concentrate on the emotional bonding between brands and consumers who live and store the brand experience as a relationship building factor in their branding strategy (Akgun et al. 2013: 504).

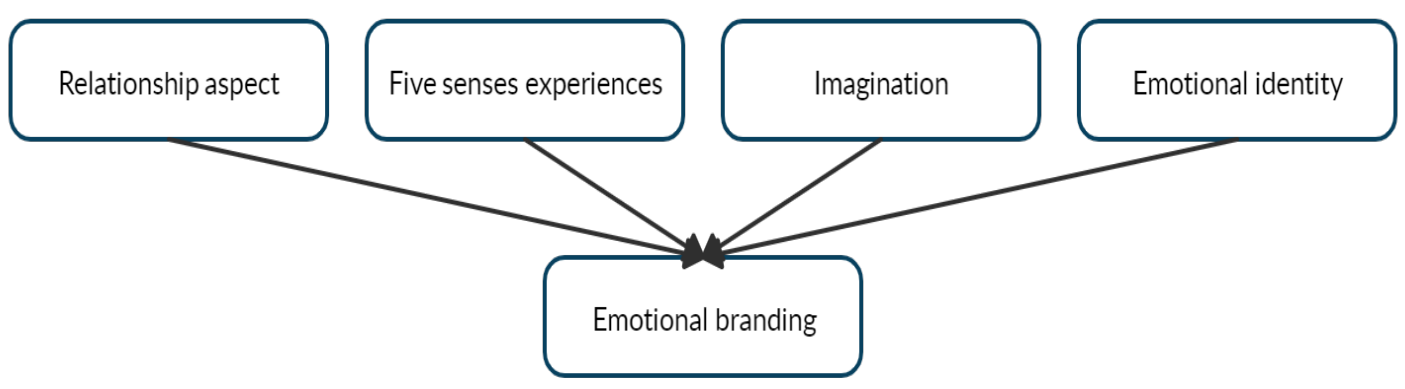

Figure 3.

Emotional branding concept by Marc Gobe

\section{Research Method}

This is a qualitative research study. According to Moleong (2010: 5-6), the qualitative research uses a scientific background to interpret a phenomenon by employing certain methods. As for the paradigm, it uses the descriptive approach. A descriptive paradigm is used to describe a condition. Other than that, it also records, analyses and interprets the current condition (Kriyantono 2009: 24). The descriptive qualitative method was used because the objective seeks a descriptive explanation of the case. The qualitative approach was chosen because this research did not try to seek out the impact, relationships or effectivity of several of the variables. Therefore the method used for this research was a case study. A case study is an intensive examination of a particular unit (Guba \& Lincoln 1981: 370).

There are several reasons for choosing a case study as the method (Guba \& Lincoln in Ahmadi 2016: 72). First, a case study gives a full description that is important to evaluate the natural environment. Second, a case study is grounded. It gives an experiential perspective, which means that it is different to most approaches that depend on instruments, designs and hypotheses. Third, a case study is holistic and lifelike. The researcher tries to offer a natural concept to its participants. Fourth, a case study simplifies the data involved. Fifth, case study focuses the attention of the reader and clarifies the meaning. The last one and the most important is that the case study communicates more than what language alone can explain. The case study builds the hidden knowledge for its readers.

Documentation is a way to collect data by giving meaning to the resources. Sutopo (2002: 64) claimed that the observation method is used for digging into certain data such as events, locations, things and pictures. Observations are applied to the research object. There are two data sources: 1) the primary data gathered from the research objects and 2) the secondary data was gathered from additional resources such as books, articles and the internet.

This research has been conducted over the course of three years. Researcher visited Nami Island in early May 2016, February 2017 and late May 2018. For every visit, the seasons were different. In 
2016, it was spring, in 2017 it was winter and 2018, it was early summer. To complete the research and to depict the subject thoroughly, the researcher got their correspondent's help for the autumn observations. During the visits, observations were done by screening the situation and taking pictures as the documentation act for every corner of Nami Island. Therefore, this research will be strengthened by the visual aspect of documentation within the researcher's analysis.

Table 1.

Case study method steps

\begin{tabular}{cl}
\hline First & Collecting the raw materials: this data consists of all of the information \\
Step about any persons and/or programs that are collected. & Constructing the case records. This simplifies the raw materials to \\
Second & organise, classify and edit the raw materials into something that is \\
Step manageable and accessible. & \\
Third Writing the case study narration. Case study shows a program or \\
Step people holisticly
\end{tabular}

\section{Results and Discussion}

The research was conducted focused on the gimmicks of Nami Island. Nami Island is a wide ranging location. Inside of the island, there are various attractions such as cafes, restaurants, theaters, exhibitions, charities, theme parks, photo taking spots etc. Nami Island attracts visitors because it was the shooting place for the popular drama, Winter Sonata and other similar dramas. In the cafes, parks or photo spots, there are many gimmicks that aim to remind the visitor of the dramas. Several gimmicks are the Winter Sonata statue, bicycles as one of the icons, the snowman icon and associated souvenirs. Emotional branding is based on four aspects: the Relationship Aspect, the Five Senses Aspect, Imagination and Emotional Identity. Therefore, this research will be divided into four stages based on the aforementioned aspects. The analysis of every aspect has been laid out through the observation results, documentation and interviews.

\section{Relationship aspect}

Relationships can be found in the emotional branding theory. The main idea behind this is the relationship between the seller with the consumer and the service provided for them as a real creature that lives, breathes and is complex. In terms of the relationship concept, one can see the change through the generations. The service for baby boomers generation, $\mathrm{X}$ generation and $\mathrm{Y}$ generation will be different. In this situation, the Y generation will be the main focus. The major consumers nowadays are of the $\mathrm{Y}$ generation.

The Y generation are also known as the millenial generation. They total $30 \%$ of the population, and this generation starts with those born in 1977. The character of this generation is one going through the integration, understanding multilayered information, growing up in the brand era, optimistic, born and raised in the psychological era and open to recycling. This generation responds to new ideas, along with the philosophy of the five sense experience, multi-generational messages and messages stating that they are smart. This is a part of the happiness/studying process, where the parents are the heros, where there is an interesting society and a sense of community. The Y generation tend to work fast and their tastes change quickly (Gobe 2003: 28).

Based on this explanation, observations were conducted three times across three seasons: spring, autumn and winter. The spring and winter were conducted through a direct observation, while the autumn was collected by correspondence and the summer was done from the internet. Based on these observations, it was found that to match the Y generation's characteristics as the most numerous viewers of Winter Sonata, the related gimmicks change every season.

Winter Sonata viewer age range goes from teenagers through to adults. The age range is the $\mathrm{Y}$ generation and above. The Y generation like quick changes in every situation. Therefore this affects 
the Winter Sonata gimmicks that are the main attraction for someone visiting Nami Island. Winter Sonata itself is a drama set in the winter season, thus most of the gimmicks are shown in the winter. However, in the spring and autumn, Winter Sonata is still the main attraction of the island. Here are the gimmicks based on the season (Figure 4).

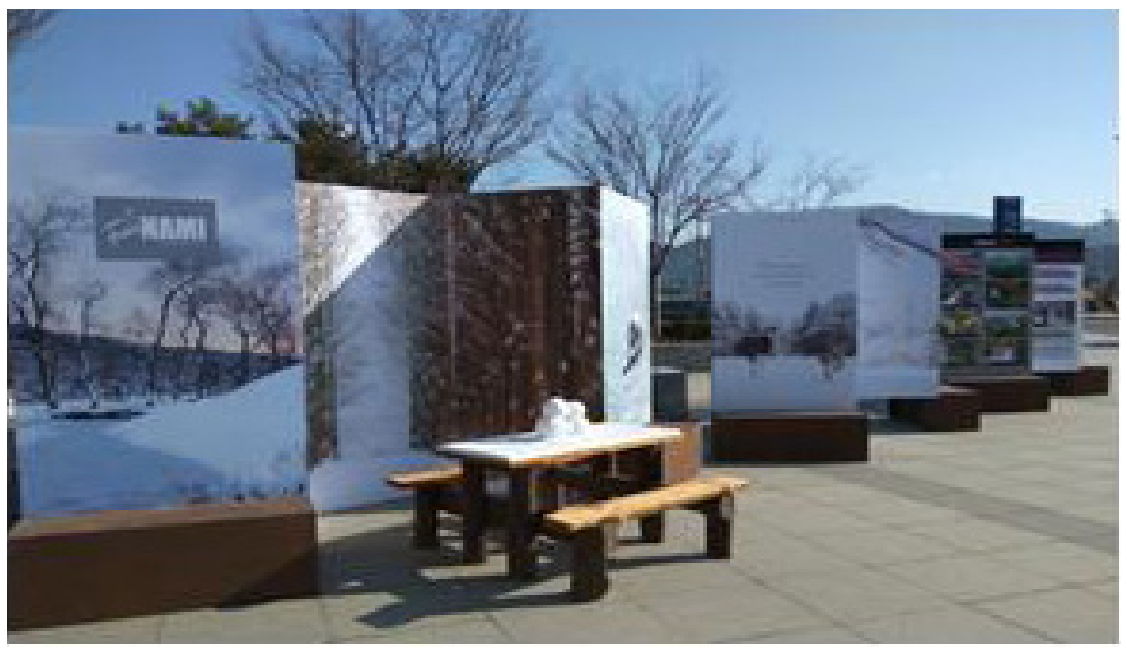

Figure 4.

First gimmick in front of Gapyeong Terminal

The changing gimmicks can be seen at the front of Gapyeong terminal. Gapyeong is the last station for the visitors who want to visit Nami Island by metro. In the metro, there are monitors that show the Nami Island video across the various seasons. The bench and background gimmicks in the above picture can be found only in the winter season. It is nowhere to be seen in other seasons. This is because the snowmen on the bench are the icon of the winter season in Winter Sonata. Figure 5 shows the brochure of Nami Island and the Nami Island Tea products. The theme is the well-known Gingko Tree Line. It is popular as it is the background of the cycling scene. The brochure can be found near to the information stand of Gapyeong station, while the teas are sold inside the cafe. The brochure will change according to the season. In the spring, it will be red, in summer it will be green and in autumn, it will be yellow.

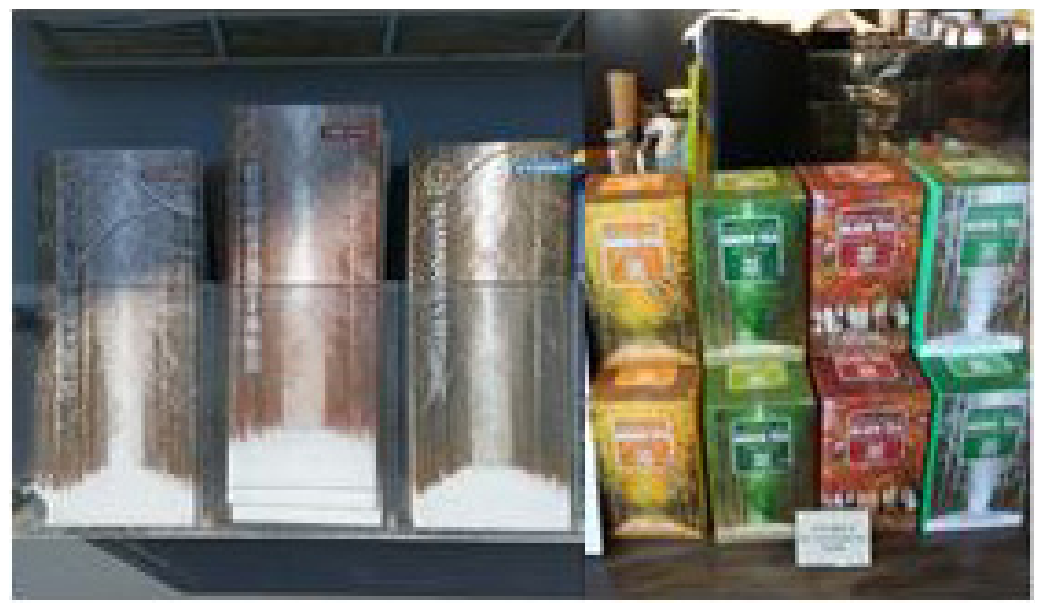

Figure 5.

The brochure and the tea by Nami Island

These snowmen can can only be seen in the winter. These snowmen are usually placed near to the ferry's dock. According to these gimmicks, change happens in every season. Winter becomes the snowman's season. There are many snowmen, starting from Gapyeong and along to the venue. Meanwhile, in the other seasons, the snowmen are less frequent than they are in winter. There are only the snowmen statues standing in line wearing the traditional clothes of several countries. 
According to Fountain and Charters (2010:50), they found that in the case of the wine tasting experience, every generation has their own characteristics. Y generations want total satisfaction. They also want connect and have deep relations with the tourism offered.

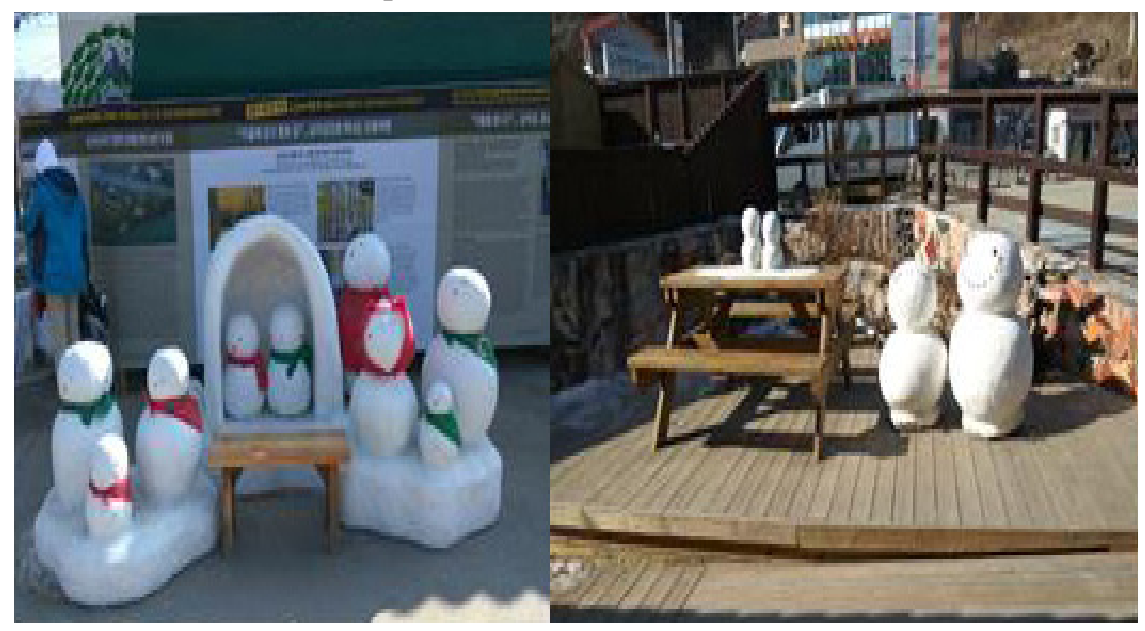

Figure 6.

Snowmen at the front gate

\section{Five sense experiences}

The five sense experiences is a part of experiential marketing. These days, there are many companies that compete when it comes to using five sense experiences as a strategy to develop their brand in the consumer's mind. In their emotional branding book, Marc Gobe stated that even though generally consumers rate the quality of the product, the lifestyle and the image of a certain product cannot be neglected either. Every product has its own symbolic quality that is brought in by the combination of the five senses and not solely because of the verbal description.

Humans have five senses, thus an experience of five senses requires marketers to maximise all five. It is not an easy task, but Michal Pham from the Columbia Graduate School of Business revealed a strategy in his works. To choose the right symbol, marketers should know the trends and the target market channel. Marketers should try to use mood strategies that relate to the end point of purchase. They should maintain an informal relationship with their consumers. The point of the five sense experiences is recognising the customer, knowing what they like, what they want and giving it to them through their senses.

The five sense elements can offer a rich and imaginative shopping experience for the customer as something inspiring. This is what Osgood defined as Associative Hierarchies. Many people are unaware of the effect of this stimulus on them, and they will claim a totally different reason. However, it is very essential for marketers to recognise this effect (Gobe 2005: 73-75). The five sense experiences that relate to the Winter Sonata drama can be seen in most of this research, mainly in the offered gimmicks.

\section{Sense of sight and sense of touch}

The sense of sight is the easiest to stimulate by marketers. In the Nami Island case, this is done by building emotional disclosure between the visitors and the Winter Sonata drama. This is done by placing a lot of snowman statues around in the winter. Winter is the peak season for stimulating the sight of the visitors. Besides all of the sights, all of the offered gimmicks can be a point at which to take a picture. Taking a picture lets someone directly experience something, such as by touching and getting close to every gimmick. Every gimmick leaves two emotional impressions in the visitors.

A snowman and a snowy bench welcomes visitors in front of the Gapyeong terminal. This reminds them of the kissing scene. The snowman icons are shown again in the giant book replica in front of Nami Island gate (Figure 7). 
Before crossing the lake to Nami, there are many snowman icons available as souvenirs. The souvenirs picture both of the characters as a cartoon and they are sold in the form of various gimmicks. There are calendars, mugs, magnets, books, notebooks etc. On some of the souvenirs, there are pictures of bicycles. This is another icon of Winter Sonata (Figure 9).

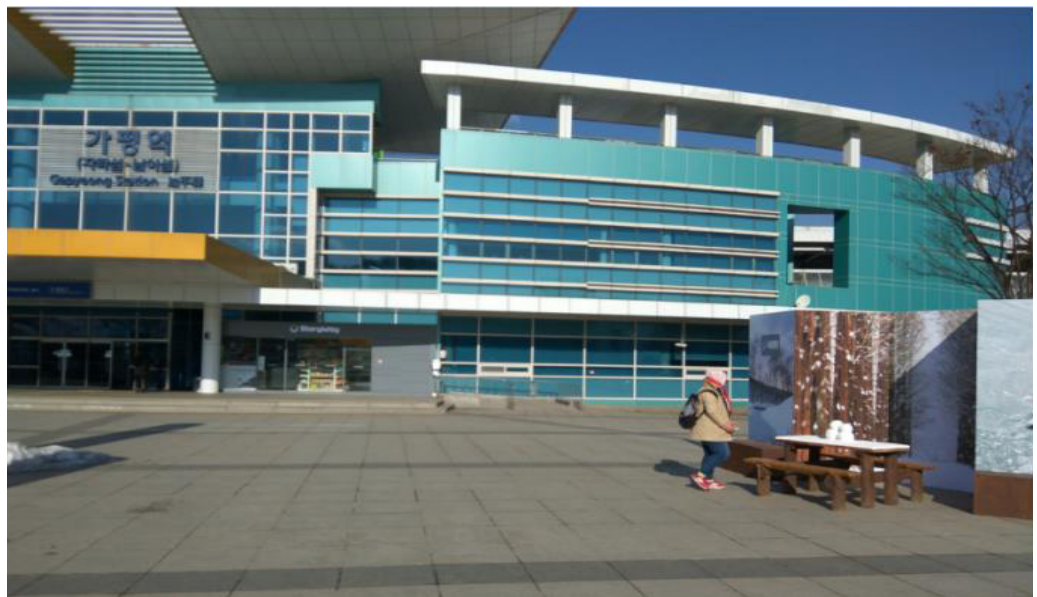

Figure 7.

Gapyeong Station and the bench

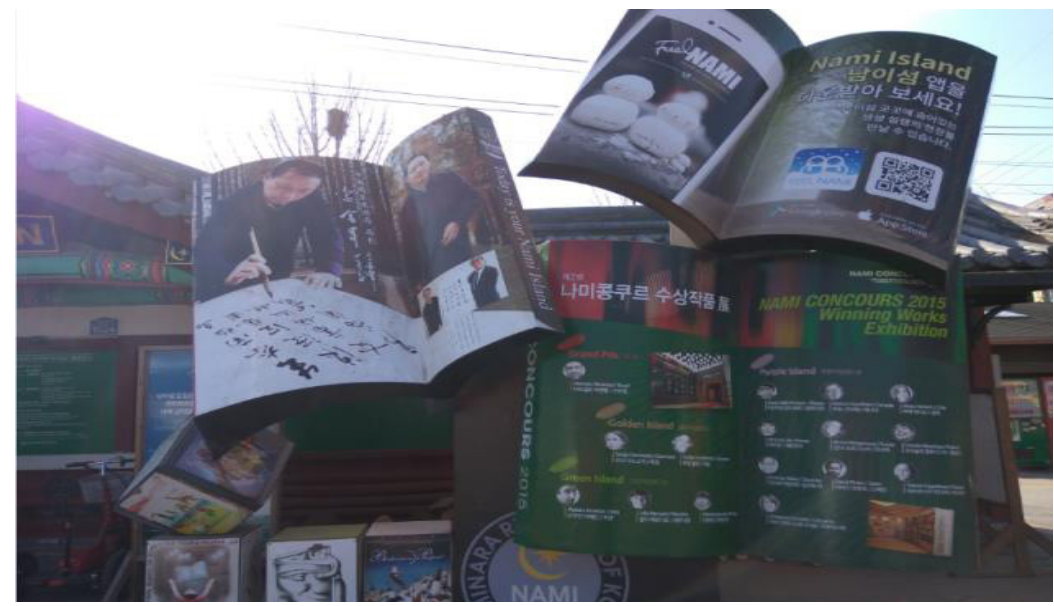

Figure 8.

Snowman picture in the book

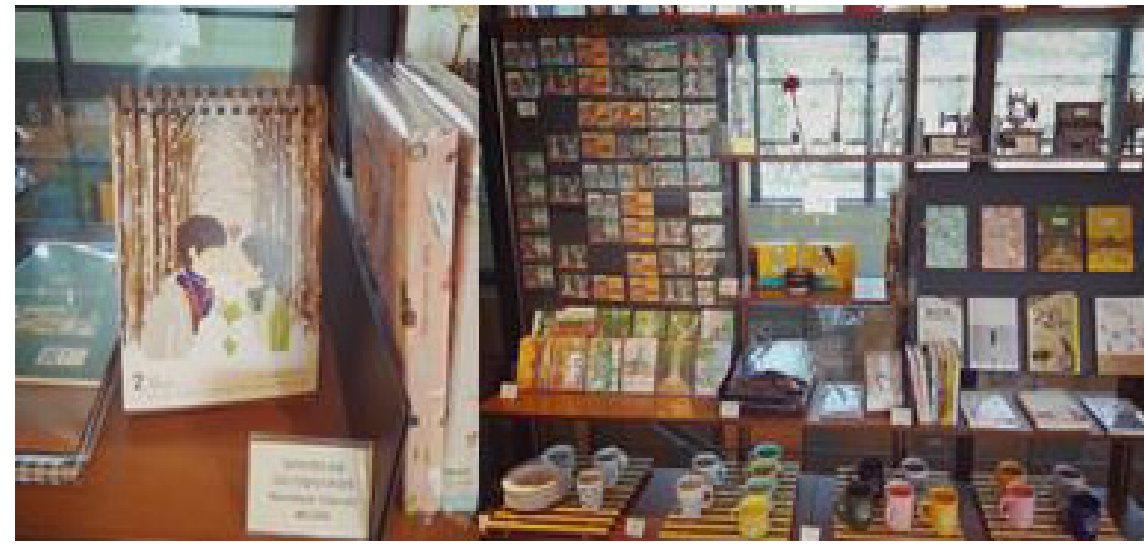

Figure 9.

Souvenirs with the Winter Sonata as the icon

In the first kiss scene location, there is a special booth for the visitors to experience sight and touch by taking a picture at the bench (Figure 10). The benches are decorated with a snowman statue, a snowy color, and pictures of the actor and actress. Beside the booth is a special booth for the director 
of four tragic dramas as a part of the The Endless Love Series. One of the restaurants put up a big Winter Sonata poster as a point of attraction for customers. Beside this, there are similar pictures in other places such as the house on the history of Nami Island. There are also bicycles and statues of both characters cycling on it. The highlight is the stone statues of both characters near to the lake.

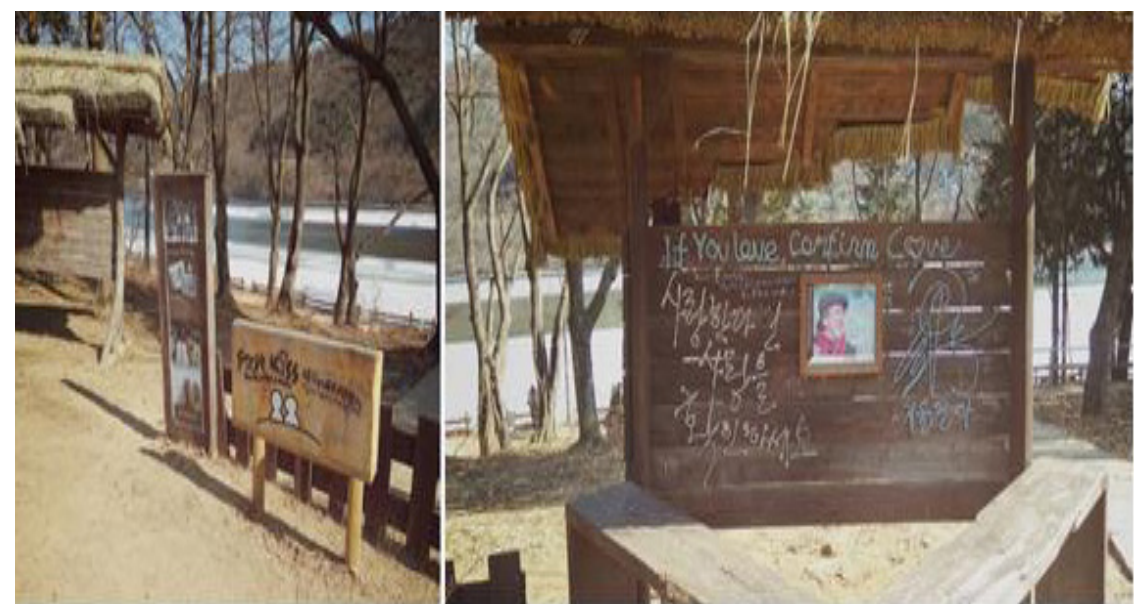

Figure 10.

Kissing scene booth and director's booth

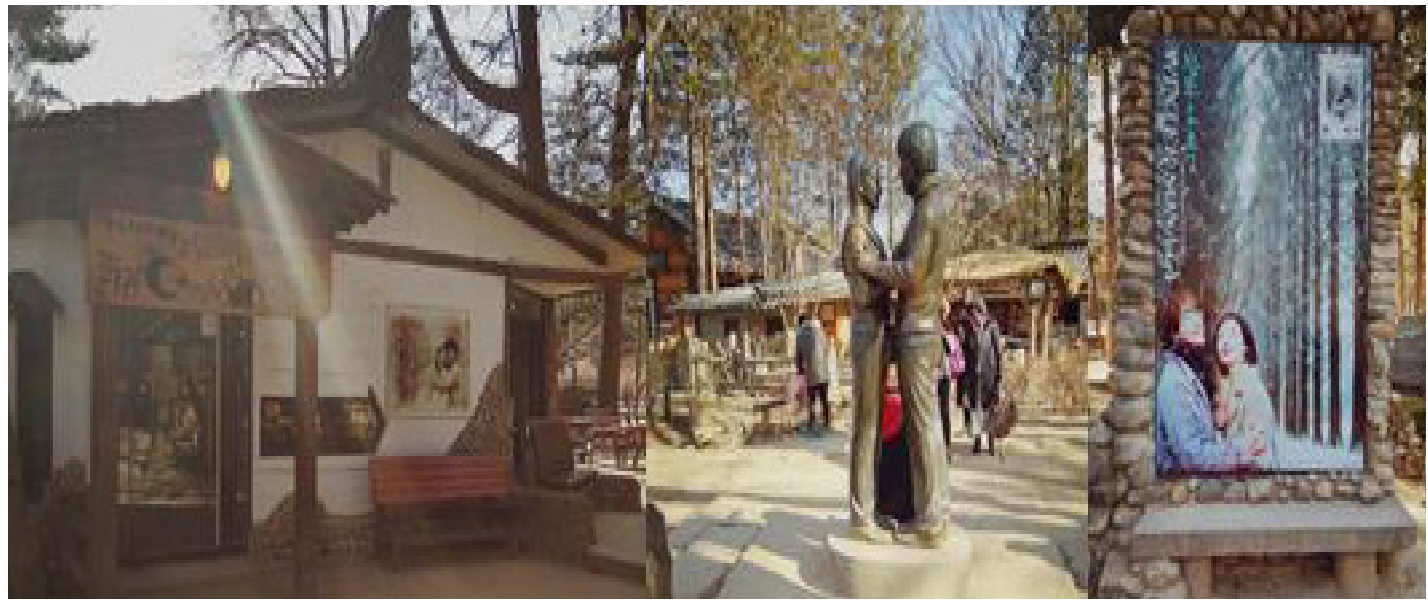

Figure 11.

Posters and Other Symbols of Nami Island

\section{Senses of smell, taste and hearing}

In this case, it has not developed yet. During the observation, there were no Winter Sonata-themed songs; smell and taste as well were neglected. Nowadays, there are many dramas that relate food or beverages, and that smell like a perfume that could be associated with the drama. Thus, people can buy the products that remind them of their favorite dramas. Since it is an old drama, experiential marketing is not well-developed yet.

Of the five human senses, sight undoubtedly has the most powerful effect on consumer perception. The famous Greek philosopher Aristotle indicated that all perceptions are triggered by witnessing. The research of Linstorm (2005) also revealed that $83 \%$ of human beings use sight as the receiver to obtain messages from among the five senses (Chang \& Lin 2010: 3344).

\section{Imagination}

Imagination in the emotional branding that is related to the design. Design is the main weapon to connect the warm feeling to the costumer. There are needs such as the basic need of individuality expression within the budget boundaries and the needs of warm and humanist objects in the cold 
hi-tech world (Gobe 2003: 116). The design should be responsive towards the customer's emotional needs and their want to enjoy the five senses through the experiences (Gobe 2003: 128). In Winter Sonata's Nami Island gimmick, there are many attractive designs. One of these involves the use of the snowman icon on various sides. At the gate, a snowman is the welcoming statue. On one of Nami's street there are twenty snowmen that are depicted wearing the traditional clothes of many countries. This design is an appreciation of the visitors and the Winter Sonata drama lovers that not only come from South Korea but also other regions as well. Another design is the effort undertaken to build the iconic scenes. Booth's first kiss is made to be similar to the original one in the drama. A snowy bench and two small snowmen share a close distance, completed by an explanation board of the scene near the booth.

On the other hand, the scene where they ride the bicycle is depicted by wooden statues posed like the actor and actress. Not only that, but there are also bicycles laid down near the tree. Pictures of both the actor and actress are displayed too.

\section{Emotional identity}

Using a logo is a symbol of the message by the company as well as a symbol of the customer's growing perception. Logos have a social sensitivity element, are culturally relevant and are an effort to find links with their customers (Gobe 2003: 130). Emotional identity and tourism cannot be separated. Because identities are constructed inside and not outside discourse, people need to understand identity as it is produced in specific historical and institutional sites within specific discursive formations and practices through specific enunciative strategies (2005: 8).

Winter Sonata is the discourse itself. The snowman is the main symbol of Nami Island. Even though there are other icons such as Gingko Tree Line and bicycle, the snowman is still the main icon of Nami Island. For Korean drama lovers, kissing scenes are the most remembered scene in a drama. It is the climax of every drama where the characters confirm their mutual love to each other. In Winter Sonata, the kissing scene used the properties of a snowy bench and snowmen. Both of the snowmans kissed to symbolise their real kiss. But then the real kiss followed. Thus, the snowman has become very popular for the viewers since the kissing scene. In seasons other than winter, the Gingko Tree Line becomes a symbol of the romantic situation between the characters. In Nami Island, the Gingko Tree Line is the favorite spot to take a picture.

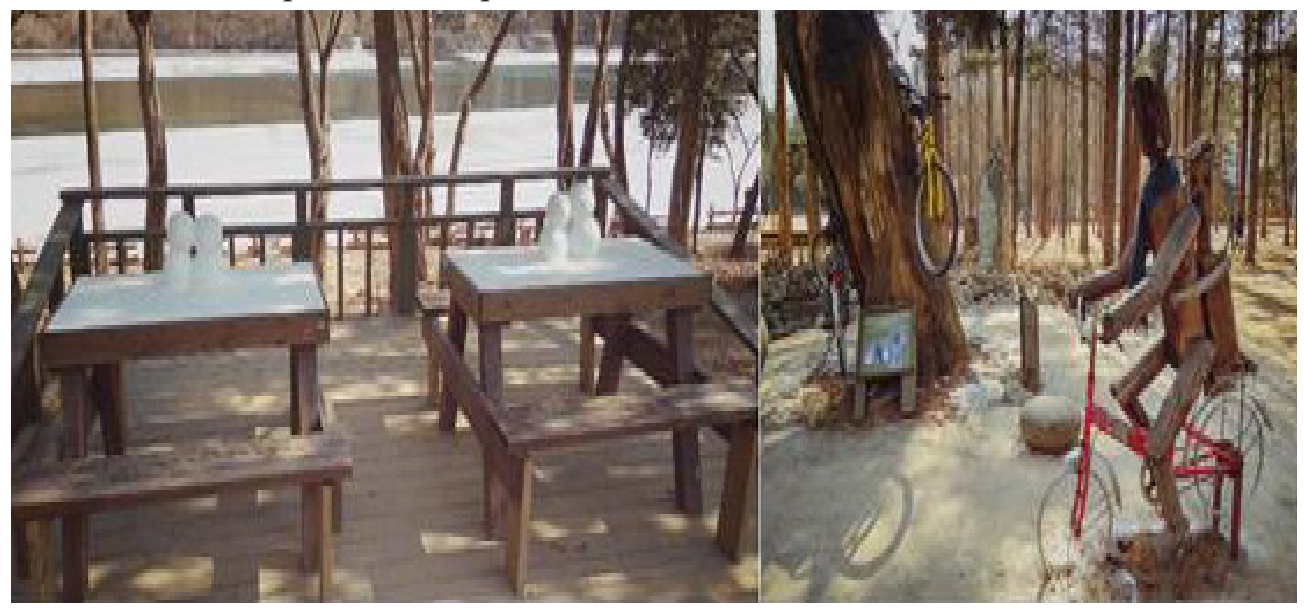

Figure 12.

The bench and the bicycles spots

\section{Conclusion}

Nami Island is a tourist place that has become popular because of drama or film. It uses the emotional branding in building the engagement of emotions between the visitors and the drama. In the Emotional Branding there are four aspects that need to be fulfilled, they are: relationship aspect, five senses experiences, imagination and emotional identity. 
The relationship aspect is fulfilled by changing the theme and properties according to the season. For the five senses experience, it only employs the senses of sight and touch by putting forward many gimmicks that can be a photo-taking hot spots. The imagination aspect is fulfilled by the unique design of the emotional identity, such as that of the snowman.

By fulfilling four of the aspects, Nami Island is successful at being the Winter Sonata Island. The viewer as the visitor can recreate their past feelings towards Winter Sonata and they can experience a unique situation in Nami Island. Since this is a continuation of the previous city branding by Semarang as a part of the cinematic city research, Semarang can adapt a similar strategy to Nami Island by linking films and potential places.

\section{References}

Ahmadi R (2016) Metodologi Penelitian Kualitatif. Yogyakarta: Ar-Ruzz Media.

Akgun AE, Kocoglu I, \& Imamoglu SZ (2013) An Emerging Consumer Experience: Emotional Branding. In: Social and Behavioral Sciences, pp. 503-508.

Chang WL \& Lin HL (2010) The impact of color traits on corporate branding. African Journal of Business Management 4 (14):3344-3355.

Ekinci Y (2003) From destination image to destination branding: An emerging area of research. Journal E-Review of Tourism Research 1 (2):21-24.

Februandari A (2012) Persepsi pelaku pasar pariwisata terhadap unsur-unsur pembentuk citra destinasi (City branding Kota Semarang). Thesis, Universitas Gadjah Mada.

Fountain J \& Charters S (2010) Generation Y as Wine Tourists: Their Expectations and Experiences At The Winery-Cellas Door. In Tourism and Generation Y. Oxfordshire: CABI.

Dinnie K (2011) City Branding: Theory and Cases. New York: Palgrave Macmillan.

Gobe M (2003) Emotional Branding: Paradigma Baru Untuk Menghubungkan Merek dengan Pelanggan. Jakarta: Erlangga.

Gobe M (2005) Emotional Branding: Paradigma Baru Untuk Menghubungkan Merek Dengan Pelanggan. Jakarta: Erlangga.

Hankinson G (2009) Managing destination brands: Establishing a theoretical foundation. Journal of Marketing Management 25 (1-2):97-115.

Guba EG \& Lincoln YS (1981) Effective Evaluation. USA: Jossey-Bass Publisher.

Kavaratzis M (2008) From city marketing to city branding: An interdisciplinary analysis with reference to Amsterdam, Budapest and Athens. Rijksuniversiteit Groningen.

Kazima M, Tembe C, Oonyu J, Clarke L, \& Abbott L (2016) A global North-South evaluation of partnership support for student teachers on placement. Policy \& Practice a Development Education Review 23:162-187.

Khan MN, Rasheed S, Islam F, Ahmed HI, \& Rizwan M (2016) Corporate branding, emotional attachment and brand loyalty: The case of luxury fashion branding. International Journal of Scientific and Research Publications 6(5):151-159.

Kriyantono R (2009) Teknik Praktis Riset Komunikasi. Jakarta: Penerbit Kencana Prenada.

Moilanen T \& Rainisto (2009) How to Brand Nations, Cities and Destinations, A Planning Book for Place Branding. USA: Palgrave Macmillan.

Moleong LJ (2010) Metode Penelitian Kualitatif. Jakarta: Rosda Karya.

Munif A (2014) Mengenal City Branding Kota Semarang. [Accessed 11 July 2016]. http:// tabloidsimpang5.com/mengenal-city-branding-kota-semarang/.

Palmer C (2005) An ethnography of englishness. Annals of Tourism Research 32 (1):7-27.

Soliha E, Rozak HA, Basiyo R, \& Purwanto U (2014) Pengaruh city branding terhadap keputusan berkunjung ke Kota Semarang. Thesis, Universitas Stikubank.

Sutopo (2002) Metode Penelitian Kualitatif. Surakarta: UNS Press.

Yusriana A, Pratiwi MR \& Mukaromah (2018) Deconstructing Indonesian film for Semarang's City branding as a cinematic city. Masyarakat, Kebudayaan dan Politik 31 (1):46-61. 